\title{
Knowledge of Teacher and Dentistry Students of a Brazilian University about a Human Teeth Bank
}

\author{
Valadas LAR ${ }^{1}$, Andrade LS ${ }^{1}$, Silva FFC ${ }^{1}$, Macedo JF ${ }^{1}$, Pinheiro LS ${ }^{1}$, Lobo PLD ${ }^{2}$, Girao Junior \\ FJ $^{1}$, Menezes LMB ${ }^{1}$
}

${ }^{1}$ Department of Pharmacy, Dentistry and Nursing College, Federal University of Ceara, Fortaleza-CE-Brazil, ${ }^{2}$ Dentistry College, Campus of Sobral, Federal University of Ceara, Fortaleza-CE-Brazil

\begin{abstract}
Human Tooth Banks (HTB) tries to overbear academic activities by providing human teeth, which are fundamental for preclinical, clinical and experimental applications. This study, which took place at the Federal University of Ceara-UFC, considered the cognition of students and professors of Dentistry on HTB. Aim: This study aimed at the investigation of the reality and importance of this tool for the undergraduate course, research as well as for the legal acquisition of this dental organ. Methods: This is a quantitative study, that a semi-structured questionnaire was used. The Statistical Package for the Social Sciences program analyzed all the data, considering the reliability of $95 \%$ and using Fisher's Exact test or the Person Chi-square test. Results: Although only $6.4 \%$ of the participants were familiarized with HTB, $99.1 \%$ considered their existence important. As for the use of human teeth, 93.5\% reported having used HTB during the course, but only $41.1 \%$ requested authorization to handle. Conclusion: The knowledge of students and professors of Dentistry about HTB and its legality in obtaining this body is insufficient, although the use of human teeth and its high importance is attributed to the existence of HTB in dental schools.
\end{abstract}

Key Words: Dental ethics, Directed tissue donation, Higher education institutions, Human tooth bank, dentistry

\section{Introduction}

The Human Teeth Banks (HTB) are philanthropic institutions linked to universities, clinics or hospitals. They aid in academic activities by supplying human teeth for scientific purposes and didactic [1].

According to the Law of Transplants in Brazil (number 9.434 Brazil, 1997), human teeth have been passed to recognize as organ [2] whose origin can't be ignored and its legal source should be starting from an HTB. Hence its use without a proven origin is considered illegal [3].

Academics and researchers of dentistry frequently use the dental organ in an illegal way, and this is a common practice in the academically centers [1]. Besides such situation be considered criminal, those teeth may not have gone by correct processing procedures: cleaning, disinfection, sterilization, and storage, what turns them a potential infection source [4].

Linked HTB to the courses of Dentistry doesn't just reduce the risk of infections crossed coming by the incorrect handling of the dental organ, but they also respect a legal norm, at the same time they organize the supply of the teeth for the students of the graduation and master's degree [5]. Since the institution HTB was created and got popularization, there was a larger perception as for the importance of the dental element as organ, fact that influenced in the increase of donations favoring the accomplished activities. [2].

With the knowledge of dentists and graduate students in Dentistry about HTB and the donation of organs, it increases the understanding about the importance of that resource and the knowledge because personal collections of teeth should not be maintained, it is necessary the incentive to the creation of HTB and the donation of teeth to the same, thereby contributing with the academic formation and scientific research in an ethical and legal way [4,5].
An evaluation of the teachers' knowledge and students of the teaching institutions has fundamental importance for a subsequent structuring of an HTB, being taken into account the characteristics of the observed territory [6].

The aim was to evaluate the knowledge of students and teachers of the Course of Dentistry in the Federal University of Ceara about HTB and to investigate the legality in the obtaining of teeth, existence, the importance of the same in the graduation and in the research according to the participants' optics.

\section{Methods}

\section{Ethical considerations}

This study was submitted to the Committee of Ethics in Research of the Federal University of Ceara and approved by number 538.659. All the participants of the research signed a Written Informed Consent Form (WICF) that explained the accomplishment of the study, the objectives, risks, and benefits to them which would be exposed, in agreement with the Guidelines and Regulator Norms of the National Council of Health (Resolution no. 466/2012).

\section{Research's delimitations}

It was a cross-sectional study, descriptive and quantitative, using a semi-structured questionnaire, with 09 questions applied in a single moment to 93 academics and 16 teachers belonging to the Dental School of the Federal University of Ceara. Previously, it was made a pilot study, not published, only to validate the questionnaire, where ten questionnaires were applied with the two investigated categories and analyzed by two teachers of Public Health, that they modified them in a way to avoid or to minimize bias. 


\section{Sample size}

The sample size was calculated using the following formula. One hundred and nine participants proportionally selected between teachers and students properly linked to the Federal University of Ceara, in the Campus of Fortaleza, participated, being obtained this way a sample that has the capacity to represent that population with $95 \%$ of confidence interval.

Sample size $(n)=[\operatorname{EDFF} \times N p(1-p)] /\left[\left(d^{2} / Z^{2}{ }_{1-\alpha / 2} \times(N-1)+p\right.\right.$ $\times(1-p)]$

Where $\mathrm{p}=0.88 ; \mathrm{N}=327 ; \alpha=0.05 ; \mathrm{EDFF}=1$

\section{Inclusion criteria}

Students regularly enrolled in activities in clinic and laboratory in the Dental School of the Federal University of Ceara and that authorized the participation in the research signing WICF; professors from Dental School of the Federal University of Ceara, selected in a random way and that they consented their participation in the referred study, signing WICF.

\section{Exclusion criteria}

Students that were not regularly registered in activities in clinic and laboratory in the Course of Dentistry; teachers retired and/or moved away from the course of Dentistry at the moment of the research.

\section{Statistical analysis}

The data were tabulated in Microsoft Excel 2010 for Windows and exported for the software Statistical Package for the Social Sciences, in which all of the analyses were accomplished considering a trust of $95 \%$. The tests Exact of Fisher or Chi-square of Pearson were used in order to accomplish the necessary statistical crossings. The chi-square test was used to evaluate the association between two qualitative variables, while Fisher's exact test was used to evaluate the statistical significance between 3 or more independent and qualitative variables. All the data were expressed in absolute and percentile form of frequencies.

\section{Results}

It was observed in the present study that $11.9 \%$ of the participants showed knowledge about the existence of Bank of Organs or Tissues, and in relation to the existence of some HTB, only $6.4 \%$ could exemplify one example, such the HTB of School of Dentistry of the University of Sao Paulo (FOUSP). Most (96.3\%) of the population in this study considered the tooth as an organ and $99.1 \%$, were in favor of the donation of organs, however, when questioned about the voluntary donation of their own dental elements, that percentile decreases to $86.2 \%$. HTB was considered important for $99.1 \%$ of the participants.

Among $93.5 \%$ of the participant's used human teeth during the graduation, half $(58.9 \%)$ used without the donor's authorization (Table 1).

Table 1. Students' and teachers general knowledge of the Course of Dentistry/FFOE/UFC on Human Teeth Bank. Fortaleza-CE, 2014.

\begin{tabular}{|c|c|c|c|}
\hline \multirow[t]{2}{*}{ General Knowledge } & \multicolumn{3}{|c|}{ Professional category } \\
\hline & Student & Professor & p-Value \\
\hline \multicolumn{4}{|l|}{ Knows Tissue Banks } \\
\hline \multirow[t]{2}{*}{ Yes } & 7 & $8^{*}$ & $<0.001$ \\
\hline & $7.50 \%$ & $50.00 \%$ & \\
\hline \multicolumn{4}{|c|}{ Knows Human Teeth Banks } \\
\hline \multirow[t]{2}{*}{ Yes } & 1 & $6^{*}$ & $<0.001$ \\
\hline & $1.10 \%$ & $37.50 \%$ & \\
\hline \multicolumn{4}{|c|}{ Considers tooth an organ } \\
\hline \multirow[t]{2}{*}{ Yes } & 90 & 15 & 0.475 \\
\hline & $96.80 \%$ & $93.80 \%$ & \\
\hline \multicolumn{4}{|c|}{ Is in favor of organ donation } \\
\hline \multirow[t]{2}{*}{ Yes } & 92 & 16 & 1 \\
\hline & $98.90 \%$ & $100.00 \%$ & \\
\hline \multicolumn{4}{|c|}{ Considers Human Teeth Bank important } \\
\hline \multirow[t]{2}{*}{ Yes } & 93 & 15 & 0.147 \\
\hline & $100.00 \%$ & $93.80 \%$ & \\
\hline \multicolumn{4}{|c|}{ Used human teeth at graduation } \\
\hline \multirow[t]{2}{*}{ Yes } & $90^{*}$ & 12 & 0.009 \\
\hline & $96.80 \%$ & $75.00 \%$ & \\
\hline \multicolumn{4}{|l|}{ If yes, which way } \\
\hline \multirow[t]{2}{*}{ University } & 32 & 5 & 0.422 \\
\hline & $32.00 \%$ & $38.50 \%$ & \\
\hline \multirow[t]{2}{*}{ Private } & 23 & 2 & \\
\hline & $23.00 \%$ & $15.40 \%$ & \\
\hline \multirow[t]{2}{*}{ Public } & 35 & 3 & \\
\hline & $35.00 \%$ & $23.10 \%$ & \\
\hline \multirow[t]{2}{*}{ No answer } & 8 & 3 & \\
\hline & $8.00 \%$ & $23.10 \%$ & \\
\hline \multirow[t]{2}{*}{ Other } & 2 & 0 & \\
\hline & $2.00 \%$ & $0.00 \%$ & \\
\hline \multicolumn{4}{|c|}{ Would donate your teeth } \\
\hline \multirow[t]{2}{*}{ Yes } & 80 & 14 & 1 \\
\hline & $87.00 \%$ & $87.50 \%$ & \\
\hline \multicolumn{4}{|c|}{ You would receive restoration (fragment collage) } \\
\hline \multirow[t]{2}{*}{ Yes } & 54 & 9 & 1,000 \\
\hline & $59.30 \%$ & $56.30 \%$ & \\
\hline \multicolumn{4}{|c|}{ Used teeth without authorization } \\
\hline \multirow[t]{2}{*}{ Yes } & 53 & 8 & 0.758 \\
\hline & $58.90 \%$ & $66.70 \%$ & \\
\hline
\end{tabular}


Table 2 shows the participants of the research that knew some HTB, all $(100 \%)$ they considered important was the equipment and $99.0 \%$ would donate their own dental elements to an HTB. Among the participants who do not know any HTB, 99\% considered the equipment important and 86.3\% would donate their teeth. Bank of Teeth did not influence any other answer once the values of $p$ were larger than 0.05 .

Table 2. The relationship between knowledge of the existence of HTB and general knowledge about human teeth bank for the professors and students of the Dental School/UFC. Fortaleza-CE, 2014.

\begin{tabular}{|c|c|c|c|c|c|}
\hline \multirow{3}{*}{ Yes } & \multicolumn{4}{|c|}{ Knows Human Teeth Bank } & \multirow[t]{3}{*}{ P-value ${ }^{*}$} \\
\hline & \multicolumn{2}{|l|}{ No } & \multicolumn{2}{|c|}{ Yes } & \\
\hline & $\mathbf{n}$ & $\%$ & $\mathbf{n}$ & $\%$ & \\
\hline Considers tooth an organ & 99 & 97.1 & 6 & 85.7 & 0.236 \\
\hline Is in favor of organ donation & 101 & 100 & 7 & 100 & 1 \\
\hline $\begin{array}{l}\text { Considers Human Teeth Bank } \\
\text { important }\end{array}$ & 101 & 100 & 7 & 100 & 1 \\
\hline $\begin{array}{l}\text { Used human teeth at } \\
\text { graduation }\end{array}$ & 96 & 95 & 5 & 71.4 & 0.065 \\
\hline \multicolumn{6}{|l|}{ Origin } \\
\hline Dentistry college & 35 & 34 & 2 & 40 & 0.78 \\
\hline Private odontological office & 24 & 23.3 & 0 & 0 & \\
\hline Public Health Unit & 32 & 31 & 2 & 40 & \\
\hline No answer & 10 & 9.8 & 1 & 20 & \\
\hline Others & 1 & 1 & 0 & 0 & \\
\hline Would donate your teeth & 88 & 86.3 & 6 & 85.7 & 0.96 \\
\hline $\begin{array}{l}\text { Used teeth without } \\
\text { authorization }\end{array}$ & 57 & 55.8 & 3 & 42.8 & 0.557 \\
\hline
\end{tabular}

${ }^{*} p<0,05$, Qui-squared test of Pearson or exact of fisher, data expressed in form of absolute frequency (percentile frequency)

Table 3. The relationship between the donation of organs and general knowledge about Human Teeth Bank for the professors and students of the Dental School/UFC. Fortaleza-CE, 2014.

\begin{tabular}{|c|c|c|c|c|c|}
\hline \multirow{3}{*}{ Yes } & \multicolumn{4}{|c|}{ Is in favor of organ donation } & \multirow[t]{3}{*}{$\begin{array}{l}\text { P- } \\
\text { Value }\end{array}$} \\
\hline & \multicolumn{2}{|c|}{ No } & \multicolumn{2}{|l|}{ Yes } & \\
\hline & $\mathbf{n}$ & $\%$ & $\mathbf{s}$ & $\%$ & \\
\hline Considers tooth an organ & 1 & 100 & 104 & 96.3 & 0.845 \\
\hline $\begin{array}{l}\text { Considers Human Teeth Bank } \\
\text { important }\end{array}$ & 1 & 100 & 107 & 99.1 & 0.923 \\
\hline Would donate your teeth & 1 & 100 & 93 & 86.1 & 0.698 \\
\hline Used teeth without authorization & 1 & 100 & 59 & 54.6 & 0.41 \\
\hline
\end{tabular}

Among the participants who agreed in favor of the donation of organs, $86.1 \%$ would donate their own teeth to an HTB, a percentile smaller when compared to the population that disagrees about the donation of organs, where 100\% would donate their dental elements to an HTB (Table 3).
In relation to the existence of an HTB, $60.6 \%$ of the participants of the research considered that the existence of equipment in the university would facilitate the academic activities a lot. The note for the importance of an HTB was $4.22 \pm 1.23$ points (Table 4 ).

Table 4. Note attributed to the importance of a human teeth bank by the professors and students of the course of dentistry/FFOE/UFC. Fortaleza-CE, 2014.

\begin{tabular}{|l|l|l|}
\hline Assigned grade & $\mathbf{n}$ & $\%$ \\
\hline 0 & 4 & 3.7 \\
\hline 1 & 1 & 0.8 \\
\hline 2 & 4 & 3.7 \\
\hline 3 & 15 & 13.8 \\
\hline 4 & 19 & 17.4 \\
\hline 5 & 66 & 60.6 \\
\hline Total & 109 & 100 \\
\hline
\end{tabular}

\section{Discussion}

Procedures that use human teeth for academic and scientific purposes should respect ethical and legal aspects, and for that, such procedures should be accomplished with a larger responsibility on the part of the researchers, professors, and students [7]. In the last years, the increase of researches in vitro that use human teeth has been brought to the surface of ethical questions around this subject, from the illegal trade to the storage of the extracted teeth and the incorrect handling [8].

In spite of the human teeth they being frequently used in Higher Education Institutions (HEI), a lacking knowledge exists on the part of the population as the existence of Bank of Organs and Tissue, especially HTB, occurred later, what may be justified is the ignorance of its existence for great part of the population, besides for students and professionals of Dentistry [4]. In the present study, accomplished in the Dental School of the Federal University of Ceara, it was observed that only $11.9 \%$ of the participants mentioned examples of Bank of Organs or Tissue and only $6.4 \%$ knew some HTB.

This present research corroborated with Pinto et al., [4] data, where in spite of more than $70 \%$ of the studied population to consider the tooth an organ, only $6 \%$ sought an HTB for the acquisition of the teeth in their activities. In the research accomplished in the Dental School of the Federal University of Ceara, $96.3 \%$ of the interviewees considered the dental element an organ, however, they didn't acquire teeth, for their experiments, through an HTB. In that same study, Pinto et al., [4] they told that $97.6 \%$ of the interviewees declared to be in favor of the donation of organs and $90 \%$ of the same ones were favoring donation of teeth for HTB. These data were similar to present work, where $99.1 \%$ of the studied population self-declared in favor of the donation of organs and $86.2 \%$ would donate their teeth for an HTB.

One research considered the implantation of HTB in HEI a fundamental process to promote the use of the dental organ in an ethical way, avoiding the illegal trade in degree courses and 
master degree of Dentistry. In the research in the subject, 99.1\% of the participants considered an HTB important [9].

The use of teeth in the courses of Dentistry is being more and more constant, however, a lot of times with inadequate use, teeth of ignored origin and those who didn't receive the necessary decontamination [3]. In this research, 93.5\% affirmed to have used teeth in academic activities, telling as origin: University of Dentistry, Private Clinic, Unit of Public Health, among others.

In the study of Pinto et al., [4] it was verified that $90 \%$ of the professionals and $86 \%$ of the graduation students confirmed the use of extracted human teeth during the Dentistry course. In that same research, $72 \%$ of the surgeondentists and $98 \%$ of the students ignored the existence of an HTB. Coincident data with the present study, where $93.5 \%$ of the participants used human teeth during the graduation and 93.6\% ignored the existence of an HTB. This is a worrying situation, because, besides the risk of acquiring crossed infections through the manipulation of contaminated biological material, there is the disrespect to the laws, because most of the time there happens illegal practices in the obtaining of the teeth, what stimulates, besides, the trade of the same ones in clinics, cemeteries, and hospitals. The knowledge of the origin of the dental organ besides a larger safety makes possible to join a larger social value, increasing the commitment and compromising in dental researches.

Researchers evaluated from the origin, decontamination, and use of the human teeth used in HEI and confirmed the existence of the illegal trade of teeth during a study in 2007 [10].

In other study, researchers sent letters with a questionnaire for 113 Brazilian HEI of Dentistry, in order to evaluate the evolution, the organizational learning and implementation of HTB in the country. A total of 36 of contacted HEI answered to the questionnaire and of those only 10 universities mentioned to have an HTB. In that same study, the authors observed the existence of HTB in the Northeast, Southeast, and South of Brazil [11].

In a similar study, Freitas et al., [8] analyzed the aspects related to the use of extracted human teeth in the degree courses and master's degree in Brazil and the existence of HTB in HEI of Dentistry. The authors verified that in 187 courses of Dentistry in the country, only 37 possessed HTB, being 21 in the Southeast area, 9 in the South area, 3 in the Northeast area, 3 in the North area and 1 in the area Centerwest.

It will be necessary in time so that the culture of valorization of the dental organ should be formed by the people. It is essential that HEI of Dentistry include information about HTB in their curricular grade, plan popularization campaigns so that students and professionals understand the importance of the ethics and legality that it involves the use of the dental organ. Professors should be followers of the use of the teeth in an ethical way, implanting protocols for its use and motivating the creation of HTB [8].

\section{Conclusion}

In agreement with the data found in the research, it is ended that few participants have knowledge of the existence of HTB, in spite of almost all have already used teeth in activities in the course of Dentistry. Those teeth, in most of the cases, were acquired in an illegal way.

Almost all participants considered the existence of an HTB important and necessary in the Institutions of Teaching in Odontology Research.

It is the necessary accomplishment of informative campaigns the use of human teeth in a legal way, a fact directly related to the implementation of HTB in HEI of Dentistry. HTB already existent should be published for the society in order to increase the knowledge as for the subject.

\section{References}

1. Nassif ACS, Tieri FA, Ana PA, Botta SB, Imparato JCP. Estruturação de um banco de dentes humanos. Pesquisa Odontológica Brasileira. 2003; 17: 70-74. (In Portuguese).

2. Gomes GM, Pupo YM, Gomes OMM, Schmidt LM, Junior VAK. Utilização de dentes humanos: aspectos éticos e legais. Revista Gaúcha de Odontologia. 2013; 61: 477-483. (In Portuguese).

3. Moreira L, Genari B, Stello R, Collares FM, Samuel SM. Banco de dentes humanos para o ensino e pesquisa em odontologia. Revista da Faculdade de Odontologia de Porto Alegre. 2009; 50 34-37. (In Portuguese).

4. Pinto SL, Silva SP, Barros LM, Tavares EP, Silva JBOR, et al. Conhecimento popular, acadêmico e profissional sobre o banco de dentes humanos. Pesquisa Brasileira em Odontopediatria Clinica Integrada. 2009; 9: 101-106. (In Portuguese).

5. Poletto MM, Moreira M, Dias MM, Lopes MGK, Lavoranti OJ, et al. Banco de dentes humanos: perfil sócio-cultural de um grupo de doadores. Revista Gaúcha de Odontologia. 2010; 58: 91-94. (In Portuguese).

6. Silva MF, Mandarino F, Sassi JF, Menezes M, Centola ALB, et al. Influência do tipo de armazenamento e do método de desinfecção de dentes extraídos sobre a adesão à estrutura dental Revista de Odontologia da Universidade da Cidade de São Paulo. 2006; 18: 175-180. (In Portuguese).

7. Vanzelli M, Imparato JCP. Histórico e Introdução. In: Banco de Dentes Humanos. 1st ed. Curitiba: Editora Maio. 2003. (In Portuguese).

8. Freitas ABDA, Pinto SL, Tavares EP, Barros LM, Castro CDL, et al. Uso de dentes humanos extraídos e os bancos de dentes nas instituições brasileiras de ensino de odontologia. Pesquisa Brasileira Odontopediatria Clínica Integrada. 2012; 12: 59-64. (In Portuguese).

9. Ferreira EL, Fariniuk LF, Cavali AEC, Baratto FF, Ambrsio AR. Banco de dentes: ética e legalidade no ensino, pesquisa e tratamento odontolgico. Revista Brasileira de Odontologia. 2003; 60: 120-112. (In Portuguese).

10. Costa SM, Mameluque S, Brando EL, Melo AEMA, Pires $\mathrm{CPAB}$, et al. Dentes humanos no ensino odontolgico: procedência, utilização, descontaminação e armazenamento pelos acadêmicos da UNIMONTES. Revista da ABENO. 2007; 7: 6-12. (In Portuguese).

11. Begosso MP, Imparato JCP, Duarte DA. Estágio atual da organização dos bancos de dentes humanos nas faculdades de Odontologia do territrio brasileiro. Revista de Pós Graduação. 2001; 8: 23-28. (In Portuguese). 